\title{
Evaluation of Bio-drying Process of Sewage Sludge using Mathematical Model of Heat and Mass Balance: Effects of Temperatures of Supplied Air and Exhaust Gas
}

\author{
Jae-Ram Park ${ }^{1 \oplus} \cdot$ Dong-Hoon Lee ${ }^{1,+\oplus} \cdot$ Kyung-Hyun Kim ${ }^{2 \odot}$ \\ ${ }^{1}$ Department of Environmental Engineering, University of Seoul \\ ${ }^{2}$ Jinenertech Inc. \\ (Received October 21, 2020; Revised November 12, 2020; Accepted November 17, 2020)
}

Objectives: The effects of temperatures of supplied air and exhaust gas on moisture removal in the bio-drying process of sewage sludge were assessed by simulating the process. We also suggested performance and efficiency indicators for moisture removal in this process and identified their effectivity.

Methods: The bio-drying process of sewage sludge was simulated by mathematical modeling of heat and mass balance under different combinations of supplied-air temperatures and control ranges of exhaust gas temperatures. The simulation results were analyzed by using some indicators for assessing the performance and efficiency of moisture removal.

Results and Discussion: While BVS (biodegradable volatile solid) degradation was inhibited at a higher supplied-air temperature and a lower control range of exhaust gas temperature, moisture reduction was enhanced at the supplied-air temperature nearer to ambient and the controlled exhaust gas temperature for 45 to $50^{\circ} \mathrm{C}$. The drying performance could be improved by the utilization of both metabolic heat and convective heat from hot supplied-air for the source of heat necessary for moisture removal. We suggested the moisture removal rate as a performance indicator, and both the moisture removing capacity of supplied-air and the mass ratio of moisture removal to BVS degradation as an efficiency indicator. We identified that this mass ratio could be an alternative for thermal efficiency of drying.

Conclusions: It is effective to control the air-flow rate to keep the exhaust gas temperature within $45 \sim 50^{\circ} \mathrm{C}$ during bio-drying of sewage sludge in terms of drying performance and efficiency. It is expected that a specified range or minimum required value for the performance and efficiency indicators in the bio-drying process which suggested in this study needs to be established.

Keywords: Bio-drying, Sewage Sludge, Heat and Mass Balance, Moisture Removal

The Korean text of this paper can be translated into multiple languages on the website of http://jksee.or.kr through Google Translator. 


\title{
열 및 물질수지 모델을 활용한 하수슬러지 Bio-drying 공정 평가: 공급공기 온도 및 배출가스 온도에 의한 영향을 중심으로
}

\author{
박재람 $^{1 \odot} \cdot$ 이동훈 $^{1+\oplus} \cdot$ 김경현 $^{2 \odot}$ \\ ${ }^{1}$ 서울시립대학교 환경공학과 \\ ${ }^{2}$ (주)진에너텍
}

목적: 하수슬러지 bio-drying 공정에서의 수분 제거에 대한 공급공기 온도 및 배출가스 온도제어범위의 영향을 본 공정의 모의를 통해 평가하였으며, 이와 더불어 bio-drying 공정의 수분 제거에 대한 성능 및 효율 지표를 제안하 고 이의 효용성을 판단하였다.

방법 : 열 및 물질수지 모델을 수립하고 공급공기 온도와 배출가스 온도제어범위의 조합을 달리하여 하수슬러지 bio-drying 공정의 모의를 수행하였다. 수분 제거에 대한 성능 및 효율 평가를 위한 지표를 선정하여 모의결과를 분석하였다.

결과 및 토의: 유기물 분해율은 공급공기 온도가 높고 배출가스 온도제어범위가 낮을수록 저감되는 반면, 수분 제 거율은 공급공기 온도가 상온에 가까울수록 $45 ~ 50^{\circ} \mathrm{C}$ 의 특정 배출가스 온도제어범위에서 증가하였다. 고온의 공기 공급에 의해 대사열 뿐만 아니라 대류열도 함께 bio-drying 공정의 건조 열원으로 활용됨으로써 건조 성능이 향상 될 수 있었다. 또한, bio-drying 공정의 성능 지표로 수분 제거속도가, 효율 지표로는 수분 제거능과 수분 제거비가 제안될 수 있으며, 특히, 수분 제거비는 열적 건조 효율을 대체할 수 있음이 확인되었다.

결론 : 하수슬러지 bio-drying 공정에서 상온의 공기를 공급하는 경우 배출가스 온도가 $45 \sim 50^{\circ} \mathrm{C}$ 범위에 존재할 수 있도록 공기공급량을 제어하는 것이 성능 및 효율 측면에서 가장 효과적인 것으로 확인되었다. 제안된 성능 및 효 율 지표의 활용에 있어 bio-drying 공정에 특정된 해당 지표의 범위 또는 최소 요구치 등의 산정이 필요할 것으로 사료된다.

주제어: 생물학적 건조, 하수슬러지, 열 및 물질수지, 수분 제거

\section{1. 서 론}

전 세계적으로 하수도 보급률 상승에 따라 하수슬러지 발 생량이 증가하고 있으며, 이의 처리 문제가 대두되고 있다. 또한, 런던협약으로 유기성폐기물의 해양투기가 전면 금지 되면서 하수슬러지의 육상처리가 의무화됨과 동시에 기후 변화 대응을 위한 신재생에너지에 관한 관심이 고조됨에 따 라 하수슬러지 자원화에 대한 기술개발이 요구되고 있다. 2018년 기준, 국내 4천여 개소의 하수처리시설에서 발생하 는 410 만 톤의 하수슬러지 중 약 $50 \%$ 가 하수처리시설 내에 서 소각(32.4\%), 연료화(30.3\%), 탄화(13.9\%), 퇴비화(3.1\%), 고화 $(0.1 \%)$ 등의 방법으로 처리되고 있고, 나머지는 외부에 서 위탁 처리되고 있다. ${ }^{1)}$ 하수슬러지는 높은 수분 함량으로 인해 어떠한 방법으로 처리를 하더라도 하수슬러지의 수분
함량을 낮추기 위한 전처리(건조)가 필수적이며2), 대부분 전 기 또는 화석연료를 사용하는 열적 건조방식을 적용하고 있 어 이의 높은 건조비용을 낮추는 방안이 요구되는 실정이다. 그러한 가운데, 기존 퇴비화와 비슷한 생물학적 처리공정 의 일종으로, 호기성 미생물에 의한 유기물의 분해 시 발생 하는 열을 이용하여 피건조물 내 수분을 신속히 건조시키는 bio-drying 공정에 관한 연구가 많은 연구자들에 의해 진행 되고 있다. Bio-drying 공정의 주된 건조 기작은 주로 '대류 성 증발'에 의한 것으로, 대사열에 의해 피건조물 표면에서 수분의 증발이 촉진되고, 증발된 수분이 수증기의 형태로 공급된 공기에 의해 배출되는 과정을 거친다. ${ }^{3)}$ 간혹 가스의 배출이 원활하지 않거나 결로현상에 의해 bio-drying 반응기 내부에서 응축수가 침출수의 형태로 누출되기도 한다. 본 공정의 최종 목적은 건조이기는 하나, 통상적인 열적 건조 
Table 1. Physico-chemical properties of feed materials.

\begin{tabular}{|c|c|c|c|c|c|}
\hline & Sewage sludge & Dried sludge & Sawdust & Mixture out & Unit \\
\hline Moisture & 81.3 & 6.0 & 6.7 & 35.0 & $\%$, wet basis \\
\hline Volatile solid & 82.5 & 84.1 & 98.2 & 87.5 & $\%$, dry basis \\
\hline Ash & 17.5 & 15.9 & 1.8 & 12.5 & $\%$, dry basis \\
\hline Carbon & 43.1 & 45.1 & 50.3 & 45.5 & $\%$, dry basis \\
\hline Hydrogen & 6.5 & 6.2 & 6.4 & 6.3 & $\%$, dry basis \\
\hline Oxygen & 23.9 & 28.9 & 38.1 & 30.2 & $\%$, dry basis \\
\hline Nitrogen & 8.1 & 3.9 & 3.4 & 5.3 & $\%$, dry basis \\
\hline Sulfur & 0.9 & n.d. & n.d. & 0.3 & $\%$, dry basis \\
\hline Higher heating value & 4,715 & 4,521 & 4,622 & 4,544 & $\mathrm{kcal} / \mathrm{kg}$, dry basis \\
\hline
\end{tabular}

Note) The properties of mixture out were simulated under temperatures of supplied air of $40^{\circ} \mathrm{C}$ and exhaust gas of 45 to $50^{\circ} \mathrm{C}$.

공정과는 달리 주요 건조 열원이 유기물 분해에 의한 대사 열이기 때문에 ${ }^{3}$, 우선적으로 유기물 분해를 원활하게 유도 하는 것이 매우 중요하다.

일반적으로 bio-drying 공정의 주요 운전 인자로써 수분 함량, 유기물 함량, 공극률, 공기공급량, 외기 온도(계절), 반 응 온도, 교반 강도 등이 유기물 분해와 수분 제거에 영향을 미치는 것으로 알려져 있다. 하수슬러지 bio-drying과 관련 하여 Huiliñir 등ㄱ)은 공기공급량과 초기 수분 함량, $\mathrm{Ma}$ 등 ${ }^{5}$ 은 팽화제의 혼합비 및 입자 크기, 공기공급량, 초기 수분 함량, Yang 등)은 초기 수분 함량과 팽화제의 종류, Zhao 등 ${ }^{7)}$ 은 공기공급량과 교반 강도, Zhao 등은 팽화제의 입자 크기와 반응 온도에 대한 영향을 파악하였다. 기존 문헌의 연구 결과를 종합해보았을 때, 반응 온도와 공기공급량이 높을수록, 팽화제의 입자 크기가 작을수록 슬러지의 건조가 더 빨리 진행되었으며, $50 \sim 70 \%$ 수준의 초기 수분 함량에서 유기물이 활발히 분해되는 것이 확인되었다. 이와 더불어 bio-drying 공정 모델링에 대한 연구도 Navaee-Ardeh 등"), Huiliñir 등 ${ }^{10)}$, Zhang 등 $^{11)}$, Zhou 등 ${ }^{12}$ 에 의해 수행되었으며, 이들이 사용한 모델은 기존 퇴비화 공정 모델링에 사용된 수식을 기반으로 몇몇 인자에 대한 변경 또는 추가된 형태 이다. 이는 퇴비화와 bio-drying 공정은 호기성 미생물의 대 사에 의한 유기물 분해 과정과 열 및 물질 전달에 대한 기 본적인 메커니즘이 동일하기 때문이다.

본 연구에서는 하수슬러지 bio-drying 공정에서의 수분 제 거에 대한 공급공기 온도와 배출가스 온도제어범위의 영향 을 파악하고자 열 및 물질수지 모델을 이용하였다. 또한, bio-drying 공정의 건조 성능 및 효율을 평가할 수 있는 지 표를 선정하고 모의결과에 적용하여 지표의 활용에 대한 효 용성을 판단하였다.

\section{2. 실험방법}

\section{1. 하수슬러지 Bio-drying 공정의 개요}

본 연구의 bio-drying 공정에서는 일일 $5,000 \mathrm{~kg}$ 의 하수슬
러지가 rotary drum type의 연속식 bio-drying 반응기(내경 $3.0 \mathrm{~m}$, 길이 $21.0 \mathrm{~m}$ )에 투입되며, 이외에도 유기물 공급을 위한 첨가제(amendment)로서의 건조슬러지(457 kg day $\left.{ }^{-1}\right)$, 통기성 향상을 위한 팽화제(bulking agent)로서의 톱밥 $\left(1,300 \mathrm{~kg} \mathrm{day}^{-1}\right)$, 호기성 분해반응의 신속한 유도를 위한 식 종제(inoculum)로서의 bio-drying 공정 배출 혼합물 $(500 \mathrm{~kg}$ $\mathrm{day}^{-1}$ )이 하수슬러지와 함께 혼합된 상태(수분 함량 약 $60 \%$ ) 로 투입된다. 각 투입물질의 물리·화학적 특성을 Table 1에 나타내었다. 반응기 전단에 투입된 슬러지 혼합물은 14 일 의 체류시간을 거쳐 반응기 후단으로 배출되는 반면, 반응 기 내에서의 유기물질의 호기성 분해와 수분의 제거(건조) 를 위해 상온 또는 가온된 공기는 반응기 내부의 각 구간 별로 공급되어 최종적으로 반응기 전단으로 배출되는 향 류(counter current)의 흐름을 가진다.

\section{2. 열 및 물질수지 모델의 수립}

유기물질의 호기성 분해는 수식 (1)과 같이 화학양론식으 로 표현될 수 있으며, 팽화제의 역할로 투입된 톱밥을 제외 하고 하수슬러지와 건조슬러지의 화학적 조성을 수식 (1)에

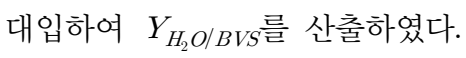

$$
\begin{gathered}
C_{a} \mathrm{H}_{b} \mathrm{O}_{c} N_{d}+\left(a+\frac{b-2 c-3 d}{4}\right) O_{2} \rightarrow \\
a \mathrm{CO}_{2}+\frac{b-3 d}{2} \mathrm{H}_{2} \mathrm{O}+d \mathrm{NH}_{3}+\text { heat }
\end{gathered}
$$

Bio-drying 공정의 열 및 물질수지에 대한 모델은 수식 (2) (13)를 이용하여 수립하였으며, 본 모델에 적용된 인자와 그 수치는 Table 2에 나타내었다. 먼저 bio-drying 공정의 물 질수지는 수식 (2)로 표현될 수 있으며, 수식 (3), (4), (5) 및 (6)은 유기물 분해에, 수식 (7)과 (8)은 수분 제거에 관여된 다. 특히 유기물 분해는 modified Gompertz equation(수식 (4))을 따르는 것으로 가정하였으며 ${ }^{13)}$, 여기에 슬러지 혼합 물의 수분 함량 및 온도에 의한 보정계수(수식 (5)와 (6))를 

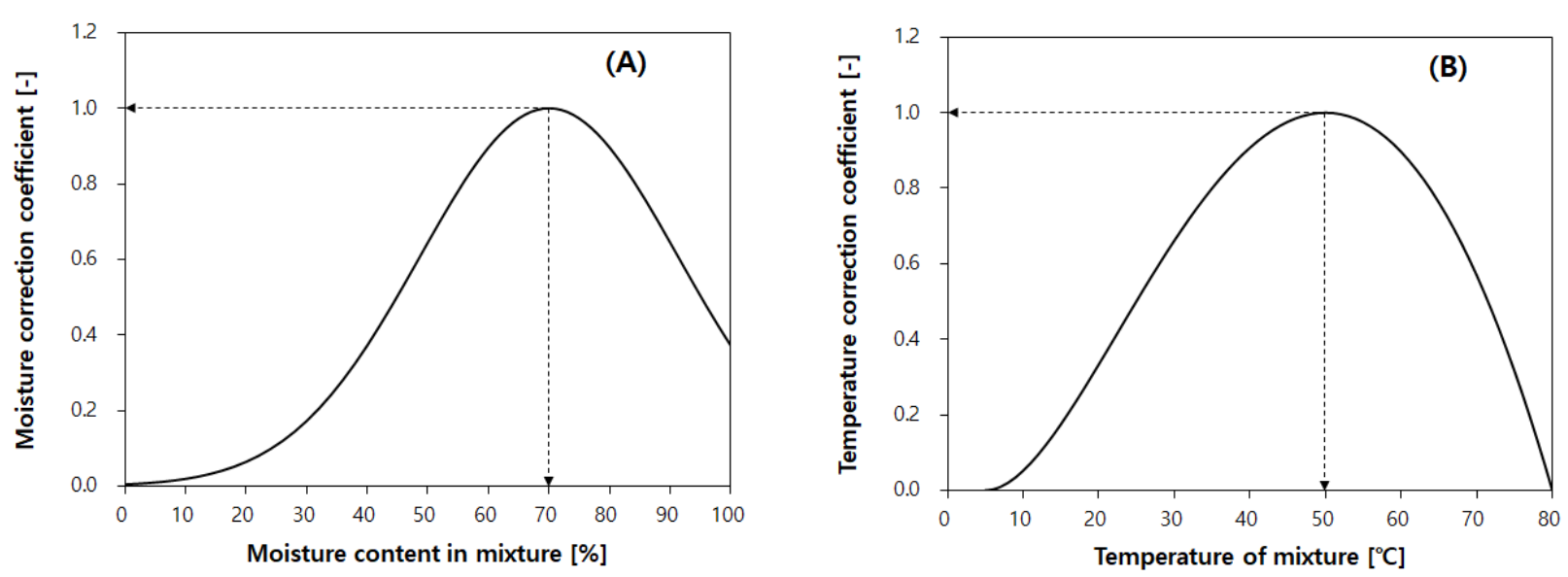

Fig. 1. Moisture (A) and temperature (B) correction coefficients for BVS degradation.

적용하였다(Fig. 1). ${ }^{14,15)}$ 또한, bio-drying 공정에서 수분은 수 증기의 형태로 제거되기 때문에 공기공급에 의한 수증기 유 입량, 가스배출에 의한 수증기 배출량이 고려되어야 하며, 이와 더불어 유기물질의 호기성 분해에 의한 대사수 생성량 도 고려되어야 한다.

$$
\Delta m=\Delta(B V S)+\Delta W
$$

여기서, $\Delta m$ : 슬러지 혼합물의 중량 변화량 $(\mathrm{kg})$

$\Delta(B V S)$ : 유기물 분해량 $(\mathrm{kg})$

$\Delta W$ : 수분 제거량 $(\mathrm{kg})$

$$
\Delta(B V S)=k_{M C} \times k_{T} \times\left(M_{t}-M_{t-1}\right)
$$

여기서, $k_{M C}$ : 수분 함량에 의한 보정계수(-)

$k_{T}$ : 온도에 의한 보정계수(-)

$M_{t}$ 또는 $M_{t-1}$ : 't' 또는 't-1' 시점까지의 누적 유

기물 분해량 $(\mathrm{kg})$

$$
M_{t}=P \times \exp \left\{-\exp \left[\frac{R_{m} \times e}{P}(\lambda-t)+1\right]\right\}
$$

여기서, $P$ : 유기물 분해 잠재량 $(\mathrm{kg})$

$R_{m}$ : 최대 유기물 분해속도 $\left.(\mathrm{kg} \mathrm{day})^{-1}\right)$

$\lambda$ : 지연기(day)

$$
k_{M C}=\exp \left\{-10.973\left(1-M C_{t}-0.3\right)^{2}\right\}
$$

여기서, $M C_{t}:$ ' $\mathrm{t}$ ' 시점에서의 슬러지 혼합물의 수분 함량(\%)

$$
k_{T}=\frac{\left(T_{t}-T_{\max }\right)\left(T_{t}-T_{\min }\right)^{2}}{\left(T_{o p t}-T_{\min }\right)\left\{\left(T_{o p t}-T_{\min }\right)\left(T_{t}-T_{o p t}\right)-\left(T_{o p t}-T_{\max }\right)\left(T_{o p t}+T_{\min }-2 \times T_{t}\right)\right\}}
$$

여기서, $T_{t}:$ ' $\mathrm{t}$ ' 시점에서의 슬러지 혼합물의 온도 $\left({ }^{\circ} \mathrm{C}\right)$

$T_{\max }$ 또는 $T_{\min }$ : 미생물 성장 온도 상한치 또는 하한치 $\left({ }^{\circ} \mathrm{C}\right)$

$T_{\text {opt }}$ : 최적 미생물 성장 온도 $\left.{ }^{\circ} \mathrm{C}\right)$

$$
\begin{aligned}
\Delta W= & W_{o}-W_{i}-W_{b i o} \\
\text { 여기서, } & W_{o} \text { : 가스배출에 의한 수증기 배출량 }(\mathrm{kg}) \\
& W_{i} \text { : 공기공급에 의한 수증기 유입량 }(\mathrm{kg}) \\
& W_{b i o}: \text { 대사수 생성량 }(\mathrm{kg})
\end{aligned}
$$

$$
W_{b i o}=Y_{H_{2} O / B V S} \times \Delta(B V S)
$$

여기서, $Y_{H_{2} O / B V S}$ 화학양론적 대사수 생성비(-)

다음으로 bio-drying 공정의 열수지는 수식 (9)로 표현될 수 있으며, 여기에는 슬러지 혼합물의 온도 변화에 의한 현 열 손실 $\left(Q_{\text {mixture }}\right)$, 유기물질의 호기성 분해에 의한 대사열 발생 $\left(Q_{b i o}\right)$, 슬러지 혼합물 내 수분의 증발에 의한 열 손실 (증발잠열, $Q_{\text {evap }}$ ), 공기공급에 의한 대류열 손실 $\left(Q_{c o n v}\right)$ 및 반응기 외벽에서 외기로의 전도열 손실 $\left(Q_{\text {cond }}\right)$ 에 대한 항이 포함되어 있다. ${ }^{16)}$ 대사열, 증발잠열, 대류열 및 전도열의 계 산은 수식 (10) (13)에 나타내었다. 전도열의 계산에 적용된 인자는 bio-drying 반응기에 대한 설계치와 제조사에서 제공 받은 물성치를 인용하였다.

$$
\left(m_{d m} \times C_{d m}+m_{w} \times C_{w}\right) \frac{\Delta T}{\Delta t}=Q_{b i o}-Q_{e v a p}-Q_{c o n v}-Q_{c o n d}
$$

여기서, $m_{d m}$ 또는 $m_{w}$ : 슬러지 혼합물 중 고형물 또는 수 분의 중량 $(\mathrm{kg})$

$C_{d m}$ 또는 $C_{w}$ : 슬러지 혼합물 중 고형물 또는 수 분의 비열 $\left(\mathrm{kcal} \mathrm{kg}^{-1}{ }^{\circ} \mathrm{C}^{-1}\right)$

$\Delta T$ : 슬러지 혼합물의 온도 변화량 $\left({ }^{\circ} \mathrm{C}\right)$

$\Delta t$ : 시간 변화량(day)

$$
Q_{b i o}=\frac{\Delta(B V S)}{\Delta t} H_{c}
$$

여기서, $H_{c}$ : 유기물 연소열 $\left(\mathrm{kcal} \mathrm{kg}^{-1}\right)$ 
Table 2. Parameters used in the model.

\begin{tabular}{|c|c|c|c|c|}
\hline Parameter & Definition & Value & Unit & Reference \\
\hline$C_{d a}$ & specific heat of dry air & 0.24 & kcal kg ${ }^{-1}{ }^{\circ} \mathrm{C}^{-1}$ & [11] \\
\hline$C_{w v}$ & specific heat of water vapor & 0.45 & kcal kg ${ }^{-1}{ }^{\circ} \mathrm{C}^{-1}$ & {$[11]$} \\
\hline$C_{d m}$ & specific heat of dry matter & 0.25 & kcal kg ${ }^{-1}{ }^{\circ} \mathrm{C}^{-1}$ & {$[11]$} \\
\hline$C_{w}$ & specific heat of water & 1.00 & kcal kg ${ }^{-1}{ }^{\circ} \mathrm{C}^{-1}$ & {$[11]$} \\
\hline$H_{c}$ & heat of combustion & 5,000 & kcal kg ${ }^{-1}$ & [7] \\
\hline$k_{a}$ & thermal conductivity of reactor wall & 1,031 & kcal $m^{-1}{ }^{\circ} \mathrm{C}^{-1}$ day $^{-1}$ & - \\
\hline$k_{b}$ & thermal conductivity of insulation material & 0.83 & kcal m ${ }^{-1}{ }^{\circ} \mathrm{C}^{-1}$ day $^{-1}$ & - \\
\hline$\lambda$ & lag-phase time & 1.0 & day & [17] \\
\hline$L$ & length of reactor & 21.0 & $\mathrm{~m}$ & - \\
\hline$P$ & BVS degradation potential & 1,132 & $\mathrm{~kg}$ & estimated \\
\hline$r_{1}$ & internal radius of reactor wall & 1.50 & $\mathrm{~m}$ & - \\
\hline$r_{2}$ & external radius of reactor wall & 1.51 & $\mathrm{~m}$ & - \\
\hline$r_{3}$ & sum of $r_{2}$ and thickness of insulation material & 1.61 & m & - \\
\hline$\rho_{d a}$ & density of dry air & 1.30 & kg m³ @STP & {$[11]$} \\
\hline$\rho_{w v}$ & density of water vapor & 0.80 & kg m @STP & [11] \\
\hline$R_{m}$ & maximum BVS degradation rate & 134 & $\mathrm{~kg}_{\text {day }}{ }^{-1}$ & estimated \\
\hline$T_{a}$ & temperature of ambient air & 20 & ${ }^{\circ} \mathrm{C}$ & assumed \\
\hline$T_{\max }$ & maximum temperature for microbial growth & 80 & ${ }^{\circ} \mathrm{C}$ & [17] \\
\hline$T_{\min }$ & minimum temperature for microbial growth & 5 & ${ }^{\circ} \mathrm{C}$ & {$[17]$} \\
\hline$T_{o p t}$ & optimum temperature for microbial growth & 50 & ${ }^{\circ} \mathrm{C}$ & {$[17]$} \\
\hline$Y_{\mathrm{H}_{2} \mathrm{O} / \mathrm{BVS}}$ & stoichiometric yield of metabolic water & 0.52 & $\mathrm{~kg}-\mathrm{H}_{2} \mathrm{O} \mathrm{kg}{ }^{-1}-\mathrm{BVS}$ & calculated \\
\hline
\end{tabular}

$$
Q_{\text {eavp }}=\left(m_{w v, o}-m_{w v, i}\right) H_{e v a p}
$$

여기서, $m_{w v, o}$ 또는 $m_{w v, i}$ : 수증기 배출량 또는 유입량 $(\mathrm{kg}$

$$
\begin{aligned}
& \text { day } \left.^{-1}\right) \\
& H_{\text {evap }} \text { : 증발잠열 }\left(\mathrm{kcal} \mathrm{kg}^{-1}\right) \\
& H_{\text {evap }}=597.6-0.57 \times T_{t}
\end{aligned}
$$

$$
Q_{\text {conv }}=\left(m_{d a, i} \times C_{d a}+m_{w v, i} \times C_{w v}\right) \times\left(T_{o}-T_{i}\right)
$$

여기서, $m_{d a, i}$ 또는 $m_{w v, i}$ : 건공기 또는 수증기 유입량 $\left(\mathrm{kg} \mathrm{day}^{-1}\right)$

$C_{d a}$ 또는 $C_{w v}$ : 건공기 또는 수증기의 비열 $\left(\mathrm{kcal} \mathrm{kg}^{-1}{ }^{\circ} \mathrm{C}^{-1}\right)$

$T_{o}$ 또는 $T_{i}$ : 배출가스 또는 공급공기 온도 $\left({ }^{\circ} \mathrm{C}\right)$

$$
Q_{\text {reactor }}=\frac{2 \pi L\left(T_{t}-T_{a}\right)}{\frac{\ln \left(\frac{r_{2}}{r_{1}}\right)}{k_{a}}+\frac{\ln \left(\frac{r_{3}}{r_{2}}\right)}{k_{b}}}
$$

여기서, $L$ : 반응기의 길이 $(\mathrm{m})$

$$
T_{a} \text { : 외기 온도 }\left({ }^{\circ} \mathrm{C}\right)
$$

$r_{1}$ : 반응기의 내경 $(\mathrm{m})$

$r_{2}$ : 반응기의 외경 $(\mathrm{m})$

$r_{3}$ : 반응기의 외경과 보온재의 두께의 합 $(\mathrm{m})$ $k_{a}$ : 반응기의 열 전도도 $\left(\mathrm{kcal} \mathrm{m} \mathrm{m}^{-1} \mathrm{C}^{-1} \mathrm{day}^{-1}\right)$ $k_{b}$ : 보온재의 열 전도도 $\left(\mathrm{kcal} \mathrm{m}{ }^{-1}{ }^{\circ} \mathrm{C}^{-1} \mathrm{day}^{-1}\right)$

\section{3. 하수슬러지 Bio-drying 공정의 모의}

하수슬러지 bio-drying 공정을 모의(simulation)하고자 반 응기 내부를 체류시간별로 14 개의 구간(구간 1 14)을 설정 하였으며(Fig.2), 반응기에 공급된 공기는 구간별 공기공급 량 대비 $\mathrm{CO}_{2}$ 발생량이 동일할 수 있도록 분배되어 체류시 간에 따른 슬러지 혼합물의 온도가 일정한 범위 내로 존재 하거나 서서히 변화될 수 있도록 유도하였다. 한편, 각 구간 에 위치한 슬러지 혼합물에 공기는 독립적으로 공급되나, 가스는 슬러지 혼합물의 이동방향과 반대인 향류의 흐름으 로 복수의 구간을 통과하여 배출되는 것으로 가정하였다. 예를 들어, 투입된 슬러지 혼합물이 '구간 1'에 머무는 동안 '구간 1'에 할당된 공기가 공급됨과 동시에, '구간 2'에서 배출된 가스 또한 '구간 1'에 공급되며, 여기서 '구간 2'에 서 배출된 가스는 '구간 2 14'에서의 공기공급에 의한 것이 다. 이와 달리, ‘구간 14 ’에는 여기에 할당된 공기만 공급되 며, ‘구간 14 '의 배출가스는 '구간 13 '으로 이동된다. 또한, 각 구간에서는 열적 평형 상태에 도달하여 배출가스와 슬러 


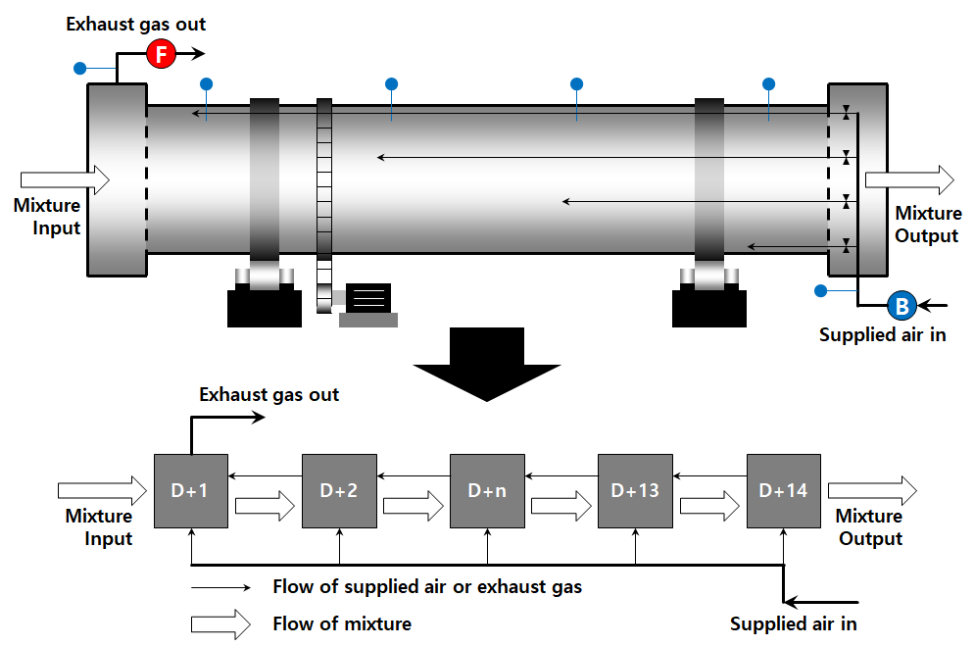

Fig. 2. Simplified model of the bio-drying reactor.

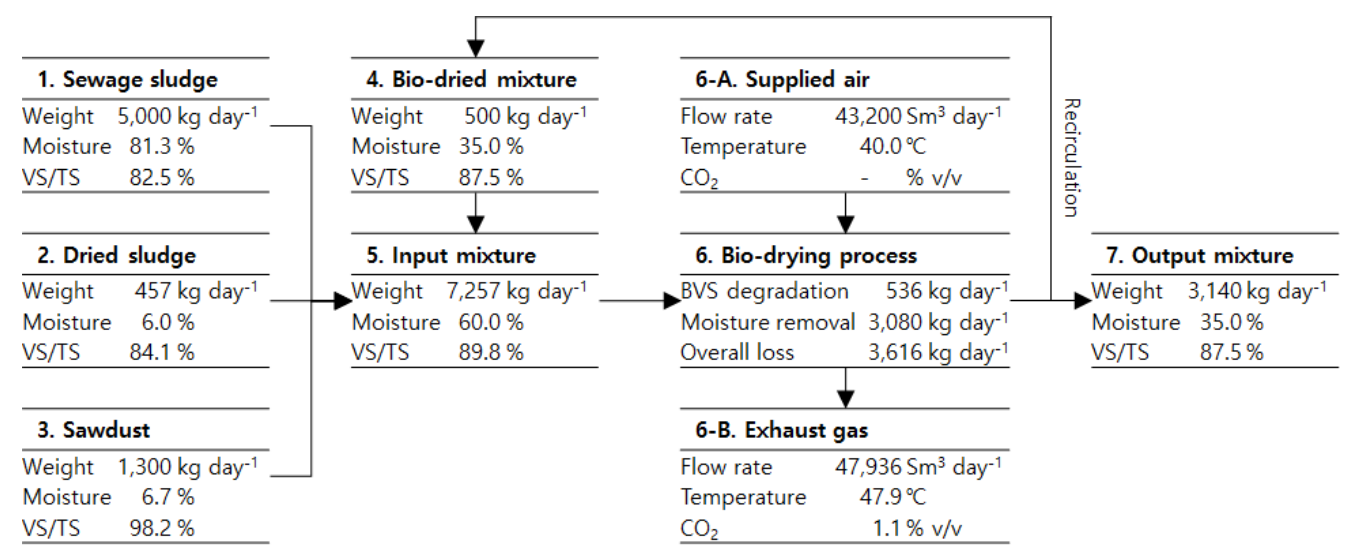

Fig. 3. Mass flow in bio-drying process of sewage sludge (simulated under temperatures of supplied air of $40^{\circ} \mathrm{C}$ and exhaust gas of 45 to $50^{\circ} \mathrm{C}$ ).

지 혼합물의 온도가 같다고 가정하였다.

본 연구의 하수슬러지 bio-drying 공정의 모의는 공급공기 온도와 배출가스 온도제어범위, 두 가지 변수에 대한 영향 을 알아보기 위해 수행되었다. 외기 온도는 $20^{\circ} \mathrm{C}$ 로 고정하 고, 공급공기 온도는 $20,30,40,50$ 및 $60^{\circ} \mathrm{C}$, 배출가스 온도 제어범위는 35 40, 40 45, 45 50, 50 55 및 55 60 ${ }^{\circ} \mathrm{C}$ 로 설 정하여 두 변수에 대한 조합을 달리하여 총 25 번의 모의를 수행하였다. 공급공기 온도는 계절적 영향을 고려한 것이 아니기 때문에 각 공급공기 온도별로 상대습도가 아닌 수증 기압를 일정하게 두어 공급공기 온도가 상이하더라도 공기 공급량이 같으면 공기공급에 의한 수증기 유입량의 차이가 없도록 하였다. Bio-drying 공정에서 배출가스 온도는 주로 공기공급량에 영향을 받기 때문에, 각 제어범위에 상응하는 공기공급량으로 $9.6,6.2,4.1,2.8$ 및 $2.1 \mathrm{~L} \mathrm{~kg}^{-1}$-mixture $\mathrm{min}^{-1}$ 을 적용하였다. 예를 들어 배출가스 온도제어범위 35 $\sim 40^{\circ} \mathrm{C}$ 에 상응하는 공기공급량은 $9.6 \mathrm{~L} \mathrm{~kg}^{-1}$-mixture ${ }_{\text {in }} \min ^{-1}$ 이다. 또한, 본 연구의 하수슬러지 bio-drying 공정의 최종 수분 함량의 목표치를 $35.0 \%$ 로 설정하였으며, 이를 앞서 언급
한 두 변수의 조합 중 중간조건에 해당하는 배출가스 온도제 어범위 $45 \sim 50^{\circ} \mathrm{C}$ 및 공급공기 온도 $40^{\circ} \mathrm{C}$ 에서 달성될 수 있도 록 열 및 물질수지 모델의 인자 중 잠재 BVS (biodegradable volatile solid) 분해량 $(P)$ 은 하수슬러지와 건조슬러지에 의한 VS (volatile solid) 투입량인 $1,132 \mathrm{~kg} \mathrm{day}^{-1}$, 최대 BVS 분해 속도 $\left(R_{m}\right)$ 는 $134 \mathrm{~kg} \mathrm{day}^{-1}$ 로 설정하였다.

\section{3. 결과 및 고찰}

\section{1. 하수슬러지 bio-drying 공정의 해석}

하수슬러지 bio-drying 공정에 대한 25 개의 모의결과 중 공 급공기 온도 $40^{\circ} \mathrm{C}$ 및 배출가스 온도제어범위 $45 \sim 50{ }^{\circ} \mathrm{C}$ 에서 의 모의결과를 중심으로 bio-drying 공정을 해석하였으며, 본 모의조건에서의 물질흐름을 Fig.3에 나타내었다. 일일 7,257 $\mathrm{kg}$, 수분 함량 $60 \%$ 의 슬러지 혼합물이 bio-drying 공정으로 투입되고, 체류시간 14 일 동안 $3,616 \mathrm{~kg}$ 의 감량(유기물 분해 $536 \mathrm{~kg}$, 수분 제거 $3,080 \mathrm{~kg}$ )이 진행되어 일일 $3,640 \mathrm{~kg}$, 수분 함량 $35 \%$ 의 슬러지 혼합물이 배출되는 것으로 모의되었다. 


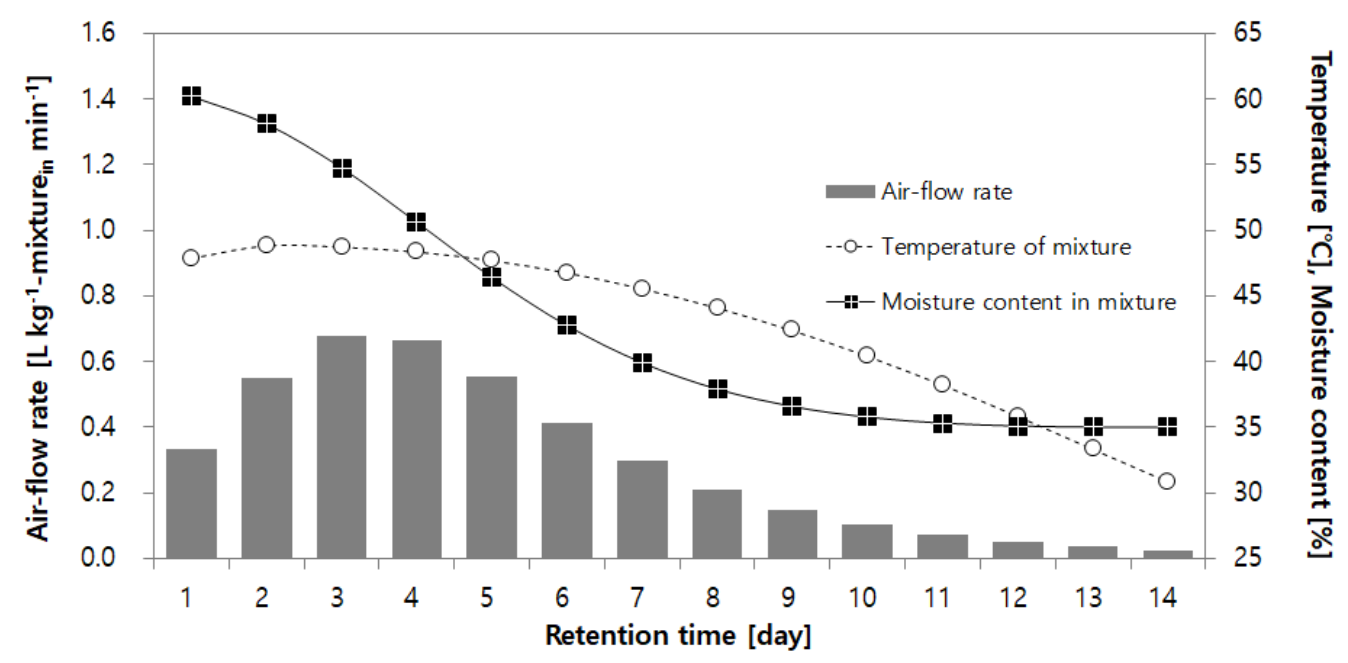

Fig. 4. Profiles of air-flow rate, temperature of mixture and moisture content in mixture during bio-drying of sewage sludge (simulated under temperatures of supplied air of $40^{\circ} \mathrm{C}$ and exhaust gas of 45 to $50^{\circ} \mathrm{C}$ ).

앞서 언급한 것과 같이, 배출되는 슬러지 혼합물의 일부(일 일 $500 \mathrm{~kg}$ )를 반송시켜 다시 하수슬러지 등과 혼합하여 bio-drying 공정으로 투입하기 때문에, 최종적인 bio-drying 공정에서 배출되는 슬러지 혼합물은 일일 $3,140 \mathrm{~kg}$ 이 된다. 한편, bio-drying 공정에서의 유기물 분해와 수분 제거를 위 해 일일 $43,200 \mathrm{Sm}^{3}, 40.0^{\circ} \mathrm{C}$ 의 공기가 bio-drying 반응기 내 슬러지 혼합물에 공급되어 일일 $47,936 \mathrm{Sm}^{3}, 47.9^{\circ} \mathrm{C}$ 의 가스 가 배출되었으며, 배출가스 내 $\mathrm{CO}_{2}$ 농도는 $1.1 \%$ 로 모의되 었다.

Fig. 4에 체류시간별 공기공급량, 슬러지 혼합물의 온도 및 수분 함량의 변화를 나타내었다. 체류시간별 공기공급량 은 슬러지 혼합물이 투입된 이후 3 4일이 지난 시점까지는 증가하다가, 이후 감소하는 패턴을 보이고 있는 반면, 슬러 지 혼합물의 온도는 체류시간 2 일에 $48.8^{\circ} \mathrm{C}$ 을 보인 이후 체 류시간 7 일까지는 $45^{\circ} \mathrm{C}$ 이상을 유지하고, 그 이후부터는 $30.9^{\circ} \mathrm{C}$ 까지 지속적으로 감소하는 것으로 모의되었다. 한편, 슬러지 혼합물의 수분 함량은 첫 7일 동안은 $39.9 \%$ 로 신속 히 낮아져 약 $20 \% \mathrm{p}$ 의 저감을 보였으나, 후반 7 일 동안은 $35.0 \%$ 까지 매우 느리게 감소하는 것으로 모의되었다. 이는 체류시간 8 일부터의 슬러지 혼합물의 낮은 온도 $\left(45^{\circ} \mathrm{C}\right.$ 미만) 와 공기공급량의 감소에 의한 것이다. 체류시간 1 일부터 7 일까지와 체류시간 8 일부터 14 일까지에 할당된 공기공급량 은 각각 총 공기공급량의 84.3 과 $15.7 \%$ 로, 슬러지 혼합물의 평균 온도는 각각 47.7 과 $37.9^{\circ} \mathrm{C}$ 로 확인되었다.

하수슬러지 bio-drying 과정에서의 유기물 분해율 및 수분 제거율은 앞서 언급한 공기공급량의 변화 패턴과 매우 유사 하게 나타났으며(Fig.5(A)), 14일 동안의 슬러지 혼합물 투 입량 대비 유기물 분해율, 수분 제거율 및 무게 감량율은 슬 러지 혼합물 투입량 대비 각각 7.4, 42.4 및 49.8\%로 모의되 었다(Table 3). 체류시간 3일에서의 유기물 분해율 및 수분 제거율은 각각 8.2 및 $1.2 \%$ 를 보이고 있으며, 총 무게 감량율
의 절반(슬러지 혼합물 투입량의 약 $25 \%$ )이 체류시간 3 4일 사이에 달성되었다. 체류시간 1 일부터 7 일까지와 체류시간 8 일부터 14 일까지의 무게 감량율은 각각 총 무게 감량율의 87.9 와 $12.1 \%$ 로 확인되었으며, 이는 앞서 언급한 공기공급 량의 할당 비율 $(84.3 \%$ vs. $15.7 \%)$ 과 슬러지 혼합물의 평균 온도 $\left(47.7^{\circ} \mathrm{C}\right.$ vs. $\left.37.9^{\circ} \mathrm{C}\right)$ 에서의 차이에 의한 것으로 설명될 수 있다. 또한, bio-drying 공정에서 수분 제거량은 가스 배 출에 의한 수증기 배출량에서 공기공급에 의한 수증기 유 입량과 유기물질의 호기성 분해에 의한 대사수 발생량을 소거함으로써 계산될 수 있으며, 본 조건의 모의결과에서 수증기 배출량, 수증기 유입량 및 대사수 발생량은 슬러지 혼합물 투입량 대비 각각 $52.4,6.1$ 및 $3.9 \%$ 로 분석되었다 (Table 3).

한편, Fig.5(B)에 나타낸 바와 같이, 대사열 발생량과 증 발잠열에 의한 열 손실량은 각각 Fig.5(A)에서 확인된 유기 물 분해율 및 수분 제거율과 같은 패턴을 보였으며, 14 일의 bio-drying 기간 동안 대사열 발생량 $\left(2,682 \mathrm{Mcal} \mathrm{day}^{-1}\right)$ 의 $71.5 \%$ 가 증발잠열로 활용되고, $20.2 \%$ 가 반응기 외벽을 통 해 외기로 손실된 것으로 모의되었다(Table 3). 나머지 8.2\% 는 슬러지 혼합물과 공급공기에 의한 현열 손실에 의한 것 이다. 이는 bio-drying 공정에서의 건조 열원은 유기물 분해 에 의한 대사열에 한정되기 때문에, 증발잠열 다음으로 높 은 반응기 외벽에서의 전도열 손실을 최소화되어야 함을 의 미한다. 체류시간 1 일부터 7일까지와 체류시간 8 일부터 14 일까지의 대사열 발생량은 각각 총 대사열 발생량의 84.3 와 $15.7 \%$ 로, 증발잠열 손실량은 각각 총 증발잠열 손실량의 88.1 과 $11.9 \%$ 로 확인되었으며, 이는 두 구간 그룹에서의 유 기물 분해량과 수분 제거량의 차이에 기인한 것이다.

또한, Fig.5(A)와 (B)의 바 그래프 상단에 나타낸 숫자는 각각 체류시간별 유기물 분해량 대비 수분 제거량과 대사열 발생량 대비 증발잠열 손실량을 의미하며, 거의 동일한 경 
Table 3. Mass and heat balance in bio-drying process of sewage sludge (simulated under temperatures of supplied air of $40^{\circ} \mathrm{C}$ and exhaust gas of 45 to $50^{\circ} \mathrm{C}$ ).

[Mass balance]

Unit: $\mathrm{kg}$ day ${ }^{-1}$ (\% of mixture in)

\begin{tabular}{|c|c|c|c|c|c|}
\hline & Input & Output & Generation & Degradation & Sum \\
\hline Volatile solid & & & & $\begin{array}{l}-536 \\
(-7.4)\end{array}$ & $\begin{array}{l}-536 \\
(-7.4)\end{array}$ \\
\hline Moisture & $\begin{array}{l}444 \\
(6.1)\end{array}$ & $\begin{array}{l}-3,806 \\
(-52.4)\end{array}$ & $\begin{array}{l}281 \\
(3.9)\end{array}$ & & $\begin{array}{l}-3,080 \\
(-42.4)\end{array}$ \\
\hline Total & $\begin{array}{l}444 \\
(6.1)\end{array}$ & $\begin{array}{l}-3,806 \\
(-52.4)\end{array}$ & $\begin{array}{l}281 \\
(3.9)\end{array}$ & $\begin{array}{l}-536 \\
(-7.4)\end{array}$ & $\begin{array}{l}-3,616 \\
(-49.8)\end{array}$ \\
\hline
\end{tabular}

[Heat balance]

Unit: Mcal day ${ }^{-1}$ (\% of sum of supply)

\begin{tabular}{|c|c|c|c|c|c|c|}
\hline & $Q_{b i o}$ & $Q_{\text {evap }}$ & $Q_{\text {mixture }}$ & $Q_{c o n v}$ & $Q_{\text {cond }}$ & Sum \\
\hline Supply & $\begin{array}{l}2,682 \\
(98.3)\end{array}$ & & $\begin{array}{c}41 \\
(1.5)\end{array}$ & $\begin{array}{c}7 \\
(0.2)\end{array}$ & & $\begin{array}{c}2,729 \\
(100.0)\end{array}$ \\
\hline Loss & & $\begin{array}{l}-1,918 \\
(-70.3)\end{array}$ & $\begin{array}{l}-148 \\
(-5.4)\end{array}$ & $\begin{array}{l}-121 \\
(-4.4)\end{array}$ & $\begin{array}{c}-543 \\
(-19.9)\end{array}$ & $\begin{array}{c}-2,729 \\
(-100.0)\end{array}$ \\
\hline Total & $\begin{array}{l}2,682 \\
(98.3)\end{array}$ & $\begin{array}{l}-1,918 \\
(-70.3)\end{array}$ & $\begin{array}{l}-107 \\
(-3.9)\end{array}$ & $\begin{array}{l}-114 \\
(-4.2)\end{array}$ & $\begin{array}{c}-543 \\
(-19.9)\end{array}$ & $\begin{array}{c}0 \\
(0.0)\end{array}$ \\
\hline
\end{tabular}
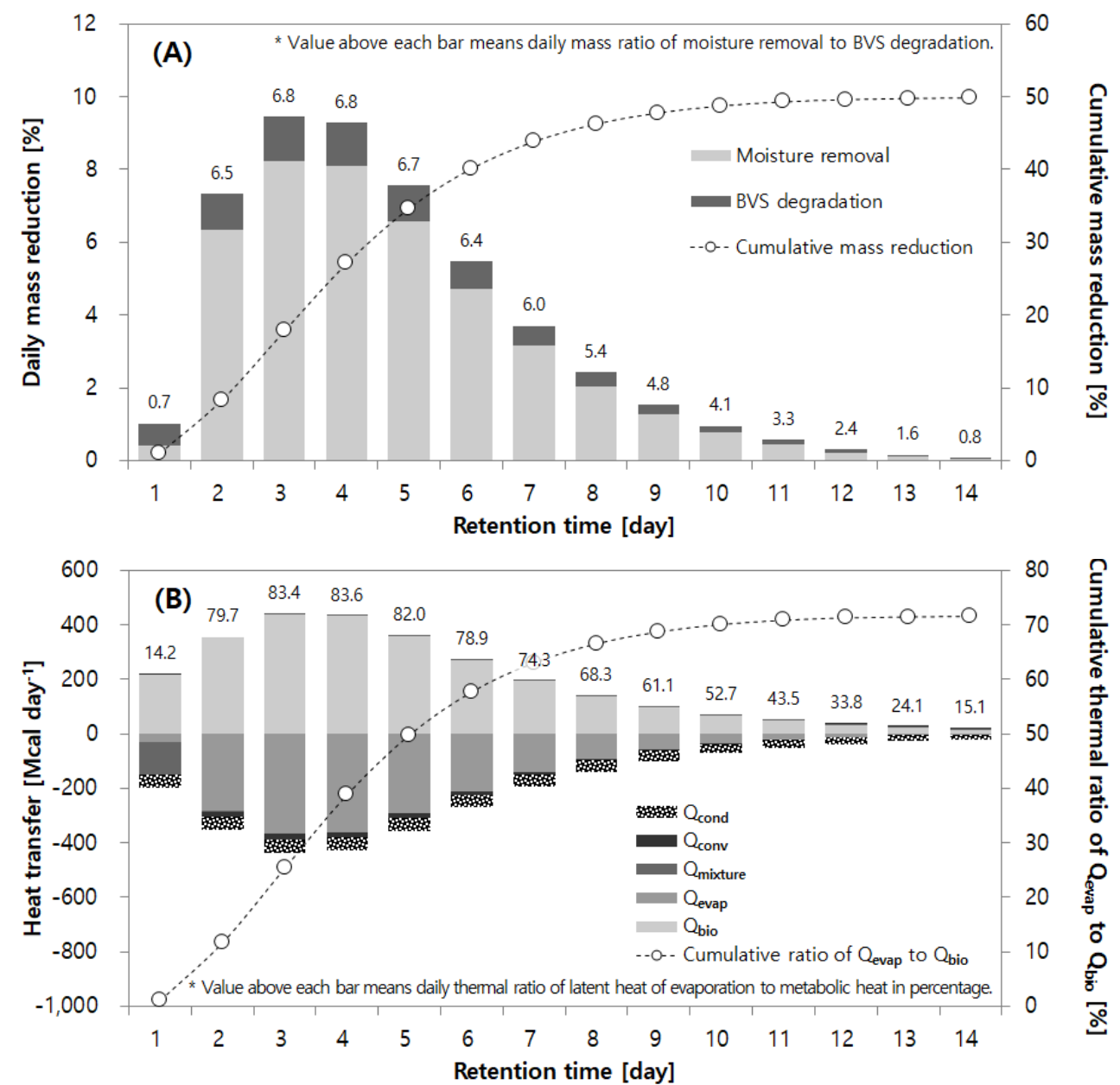

Fig. 5. Mass reduction (A) and heat transfer (B) during bio-drying of sewage sludge (simulated under temperatures of supplied air of $40^{\circ} \mathrm{C}$ and exhaust gas of 45 to $50^{\circ} \mathrm{C}$ ). 


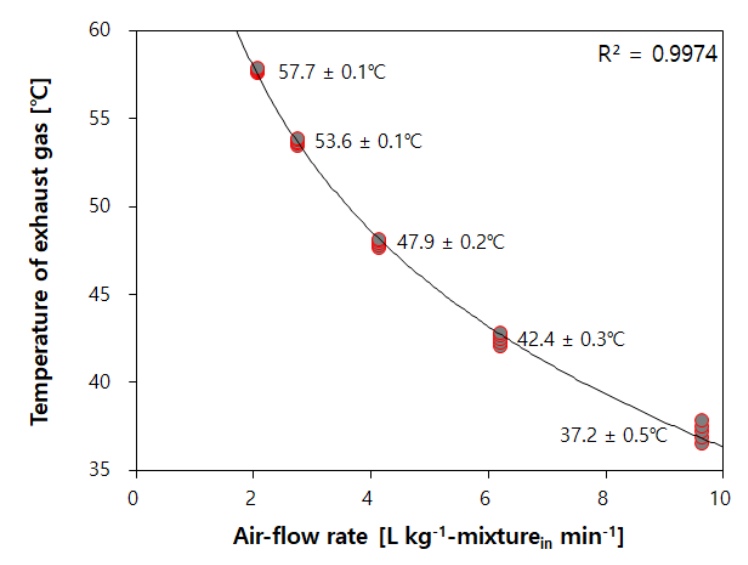

Fig. 6. Relationship between air-flow rate and temperature of exhaust gas.

향성을 보임이 확인되었다(결정계수 0.9999). 특히 체류시 간 1 일에서는 공기공급량과 슬러지 혼합물의 온도가 낮지 않았음에도 불구하고 수분 제거율이 $0.4 \%$, 유기물 분해량 대비 수분 제거량이 0.7 로 매우 낮았는데, 해당 시점에서의 대사열 발생량 대비 증발잠열 손실량이 $14.2 \%$ 로 낮은 것과 부합하였다. 이는 대사열 발생량이 적지 않으나 $(216 \mathrm{Mcal}$ $\mathrm{day}^{-1}$ ) 이 중 상당한 부분이 새로 투입된 슬러지 혼합물의 온도 $\left(20^{\circ} \mathrm{C}\right)$ 를 상승시키는 데에 현열 $\left(143 \mathrm{Mcal} \mathrm{day}^{-1}\right)$ 로 소비 되고 증발잠열(31 Mcal day ${ }^{-1}$ 로 활용되지 않았기 때문인 것
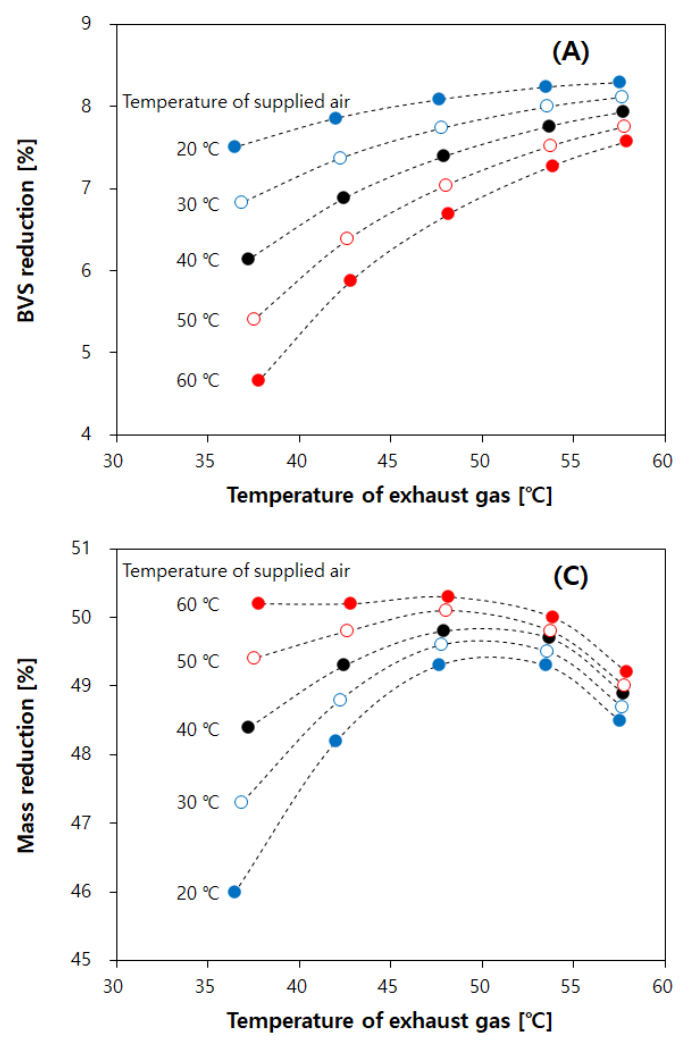

으로 설명될 수 있다.

\section{2. 하수슬러지 bio-drying 공정에 대한 공급공기 온도 및 배출가스 온도제어범위의 영향}

일반적으로 bio-drying 공정은 공기공급량, 수분 함량, 유 기물 함량, 외기 온도(계절), 공극률, 교반 강도 등에 영향을 받는 것으로 알려져 있으나-8), 본 연구에서는 공급공기 온 도와 배출가스 온도제어범위에 국한하여 열 및 물질수지 모 델을 이용한 모의를 통해 이의 영향을 파악하고자 하였으 며, 특히, 배출가스 온도제어범위는 공기공급량을 달리 적 용함으로써 변경되었다. 이미 알려진 바와 같이 ${ }^{18)}$, 공기공급 량이 클수록 공급공기의 냉각효과에 의해 배출가스 온도는 감소하는 경향이 본 연구의 모의결과에서도 도출되었다(결 정계수 0.9974). 또한, 동일 공기공급량 조건에서 공급공기 온도의 변화에 배출가스 온도는 크게 상이하지 않으나(변동 계수로서 최대 $1.4 \%$ 이하), 공기공급량이 클수록 서로 다른 공급공기 온도에서의 배출가스 온도의 변동계수는 미미하 게 증가하는 것으로 모의되었다(Fig. 6).

유기물의 호기성 분해 시 발생되는 대사열이 주된 건조 열원으로 활용되는 bio-drying 공정에서 유기물 분해 정도는 공기공급량과 함께 수분 제거에 영향을 미치는 매우 중요한 요소이다. Fig.7(A)에 공급공기 온도 및 배출가스 온도에 따
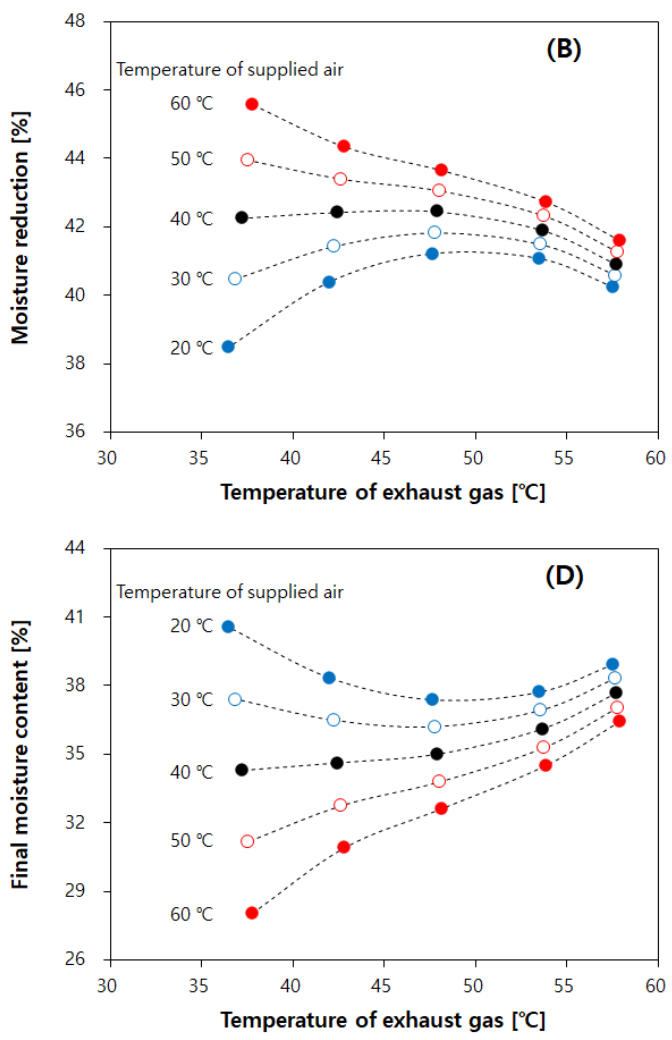

Fig. 7. BVS, moisture and mass reductions (A, B, C) and final moisture content in sludge mixture (D) under different temperatures of supplied air and exhaust gas. 

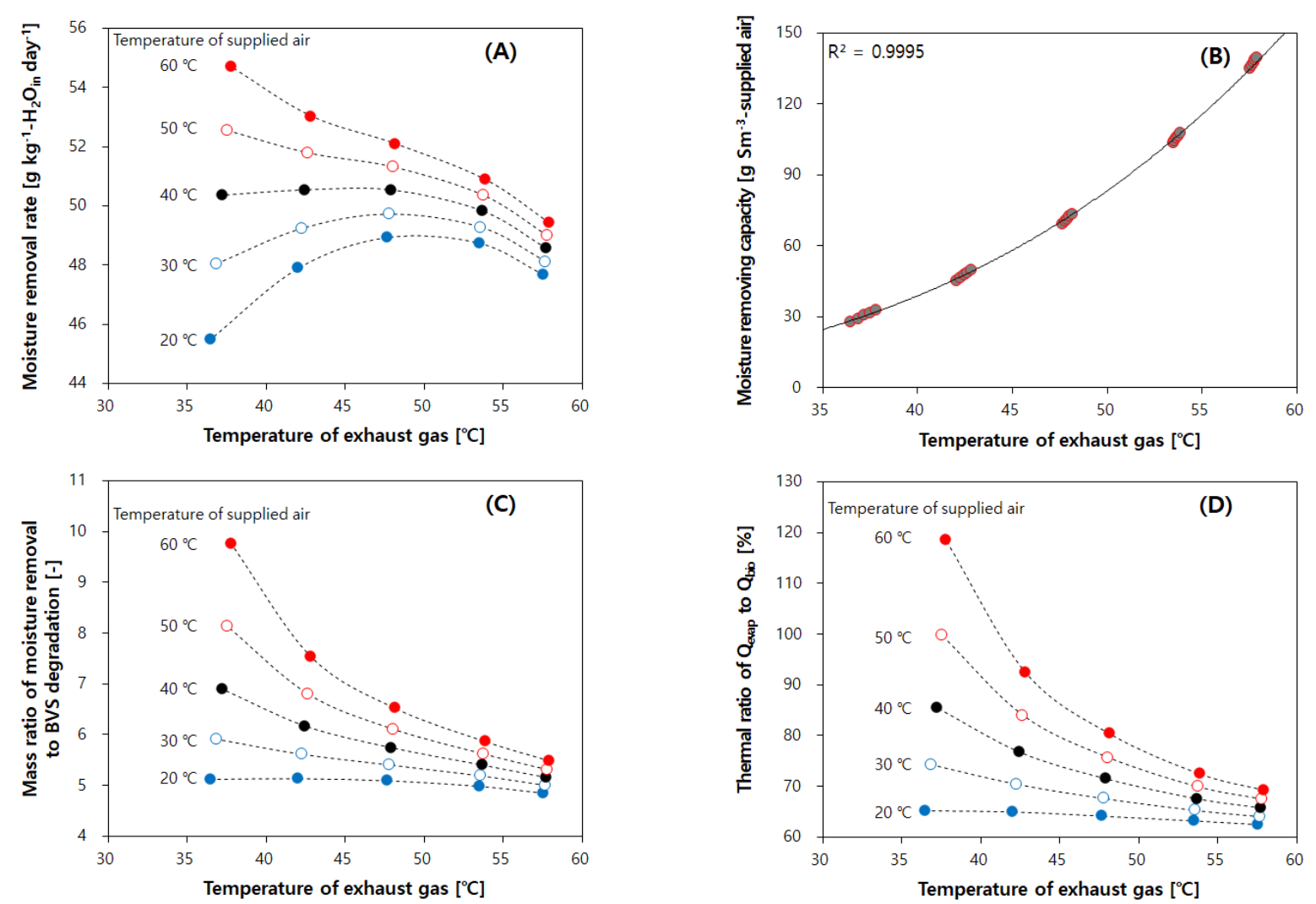

Fig. 8. Moisture removal rate (A), moisture removing capacity (B), mass ratio of moisture removal to BVS degadation (C) and thermal ratio of $Q_{\text {evap }}$ to $Q_{\text {bio }}(\mathrm{D})$ under different temperatures of supplied air and exhaust gas.

른 유기물(BVS)의 분해율(슬러지 혼합물 투입량 대비)에 대 한 모의결과를 나타내었다. 유기물 분해속도를 결정하는 호 기성 미생물의 대사속도는 온도와 수분 함량에 영향을 받는 데 ${ }^{19)}$, 배출가스 온도가 낮을수록, 즉 bio-drying 반응기 내 슬러지 혼합물의 온도가 낮을수록 유기물 분해율이 감소하 는 것이 확인되었으며, 공급공기 온도가 높을수록 슬러지 혼합물의 건조가 빠르게 진행되어 수분 함량이 낮아짐에 의 해서도(Fig.7(D)) 유기물 분해율이 감소하는 것으로 모의되 었다.

Bio-drying 공정에서 대부분의 무게 감량을 차지하는 수 분 제거율(슬러지 혼합물 투입량 대비)은 공급공기 온도가 $40^{\circ} \mathrm{C}$ 이상일 경우, 일반적인 건조 공정에서와 마찬가지로, 공급공기 온도가 높고 배출가스 온도가 낮을수록(공기공급 량이 높을수록) 증가하는 것으로 모의되었다(Fig.7(B)). 이 와 관련하여, 공급공기를 가온하여 음식물류폐기물을 대상 으로 bio-drying 실험을 수행한 $\mathrm{Ma}$ 등 $^{20)}$ 은 가온된 공기의 공급에 의한 수분 제거의 향상을 확인하였다. 그러나 공급공 기 온도가 $40^{\circ} \mathrm{C}$ 미만일 경우에는 배출가스 온도가 $45 \sim 500^{\circ} \mathrm{C}$ 사이에 존재할 때 수분 제거율이 가장 높았으며, 배출가스 온도가 이보다 높거나 낮으면 오히려 수분 제거율이 감소 하는 것이 확인되었다. 슬러지 혼합물의 최종 수분 함량도 마찬가지로 $45 \sim 50^{\circ} \mathrm{C}$ 의 배출가스 온도에서 가장 낮았으며
(Fig.7(D)), 이러한 모의결과는 bio-drying 공정에서 효과적 인 수분 제거를 위한 최적 운전 온도로 $45^{\circ} \mathrm{C}$ 가 권장되는 것 ${ }^{3)}$ 과 일치한다. 한편, 유기물 분해율과 수분 제거율의 합, 즉 무 게 감량율은 공급공기 온도가 높을수록 증가하나, 수분 제거 율과는 달리 공급공기 온도와 관계없이 배출가스 온도가 $45 \sim 50^{\circ} \mathrm{C}$ 사이일 때 가장 높은 것으로 모의되었다(Fig. 7(C)).

본 연구에서는 bio-drying 공정의 수분 제거에 대한 성능 과 효율을 평가할 수 있는 지표를 제안하고, 모의조건(공급 공기 온도 및 배출가스 온도제어범위)에 따른 영향을 파악 하고자 하였다. 성능 지표에 해당하는 '수분 제거속도'는 주 어진 시간 내에 얼마나 많은 수분이 제거되었는지를 의미하 고, 효율 지표에 해당하는 '수분 제거능'과 '수분 제거비'는 bio-drying 기간 동안 공급된 공기 또는 분해된 유기물에 의 해 얼마나 많은 수분이 제어되었는지를 의미한다. 먼저, 수 분 제거속도에 대한 공급공기의 온도와 배출가스 온도의 영 향(Fig. 8(A))을 살펴보면, 앞서 Fig. 7(B)에서 확인된 바와 같이, 공급공기 온도가 $40^{\circ} \mathrm{C}$ 를 초과하는 경우에는 공급공기 온도가 높고 배출가스 온도가 낮을수록(공기공급량이 높을수 록) 수분 제거속도가 증가하고, 반면 공급공기 온도가 $40^{\circ} \mathrm{C}$ 이하인 경우에는 배출가스 온도가 $45 ~ 500^{\circ} \mathrm{C}$ 사이에 존재할 때 수분 제거속도가 가장 높았으며, 배출가스 온도가 이보 다 높거나 낮으면 오히려 감소하는 것이 확인되었다. 


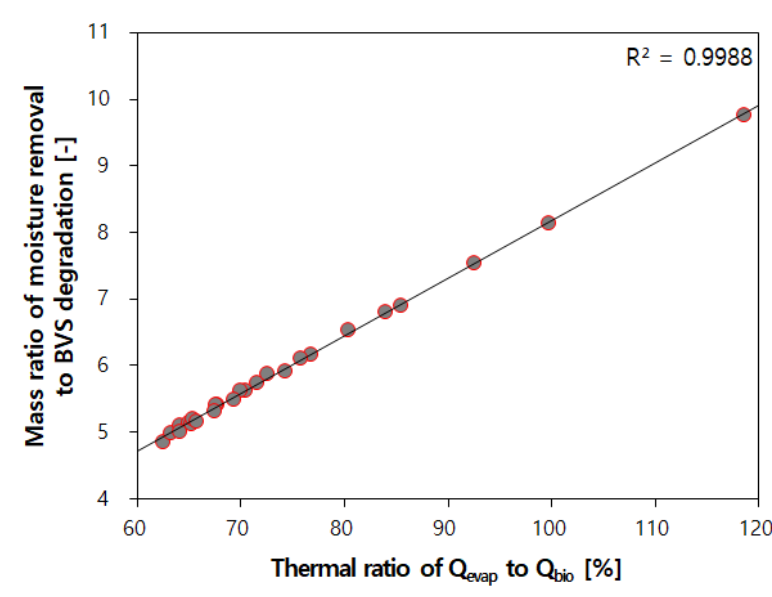

Fig. 9. Relationship between thermal ratio of $Q_{\text {evap }}$ to $Q_{\text {bio }}$ and mass ratio of moisture removal to BVS degradation.

다음으로 bio-drying 공정의 효율 지표 중 하나인 수분 제 거능은 공급공기 온도와 관계없이 배출가스 온도의 증가(공 기공급량의 감소)와 함께 높아지는 것을 확인할 수 있으며 (Fig. 8(B)), 이는 온도에 따른 공기의 포화 수증기압 또는 수 증기 보유능과 밀접한 관련이 있다. 본 연구에서 bio-drying 공정의 모의 시, 공급공기 온도에 따른 절대습도는 동일하게 설정하여 공기공급량이 같으면 공급공기 온도가 달라지더라 도 공급공기의 수증기 보유량이 동일하기 때문에, 공급공기 의 수분 제거능(수증기 보유능과 보유량의 차이)은 결국 배 출가스 온도에 의해 결정되는 것으로 볼 수 있다.

Bio-drying 공정에서의 건조 열원은 대부분 유기물질의 호 기성 분해 시 발생되는 대사열로써, 대사열 발생량 대비 증 발잠열 손실량의 계산을 통해 수분 제거에 대한 bio-drying 공정의 열적 효율을 도출할 수 있다. 그러나 본 공정의 열수 지를 수립하기가 절대 간단하지 않고 그 계산과정이 매우 복잡하기 때문에, 이에 대한 대안으로 본 연구에서는 수분 제거비라는 지표를 제안하고자 한다. Fig.9에 대사열 발생 량 대비 증발잠열 손실량과 수분 제거비의 관계를 나타내었 으며, 이 둘의 경향성이 거의 일치하는 것으로 파악되었다 (결정계수 0.9988). 이는 수분 제거비가 bio-drying 공정의 열적 효율을 나타내는 지표로 활용될 수 있음을 의미한다.

한편, 수분 제거비는 공급공기 온도가 높고 배출가스 온 도가 낮을수록(공기공급량이 높을수록) 증가하였으며, 이는

Fig.7(A)에서 살펴본 바와 같이, 수분 제거비의 분모에 해당 하는 유기물 분해율이 감소하기 때문으로 파악된다. 대사열 발생량 대비 증발잠열 손실량 역시 수분 제거비와 같은 영 향을 받는 것으로 분석되었는데, 공기공급 온도 50 과 $60^{\circ} \mathrm{C}$, 배출가스 온도제어범위 $35 \sim 40^{\circ} \mathrm{C}$ 인 모의조건에서 이 비율이 각각 $100 \%$ 에 가깝거나 $(99.7 \%)$ 초과하는 것(118.6\%)으로 확 인되었다. 이는 수분 제거에 순수하게 대사열만 활용된 것 이 아니라, 고온의 공기에 의해 공급되는 대류열도 활용되 었음을 의미한다.

\section{4. 결 론}

본 연구에서는 대규모 실험장치를 이용하여 다양한 운전 조건에서의 실제 실험결과를 도출하는 데 어려움이 존재하 는바, 열 및 물질수지 모델을 이용하여 여러 운전조건 중 공 급공기 온도 및 배출가스 온도제어범위의 변화에 대한 하수 슬러지 bio-drying 공정을 모의하고, 모의조건에 따른 건조 성능 및 효율을 평가하여 다음의 결론이 도출되었다. 본 연 구가 실제 실험결과가 아닌 모의결과에 대한 분석을 통해 진행되었다는 한계가 존재하기는 하나, bio-drying 공정에 대한 이해도를 높이는데 도움이 될 수 있을 것으로 사료된 다. 또한, 실제 실험결과와의 비교를 통한 본 연구에 적용된 열 및 물질수지 모델의 입증과 함께, bio-drying 공정의 기 타 운전 인자(수분 함량, 유기물 함량, 공극률, 외기 온도, 단열 정도 등)의 영향에 대한 추가적인 연구가 수행되어야 할 것으로 판단된다.

1) 상온의 공기를 공급하는 경우, 배출가스 온도가 $45 \sim 50^{\circ} \mathrm{C}$ 범위에 존재할 수 있도록 공기공급량을 제어하는 것이 건조 성능 및 효율 측면에서 가장 효과적인 것으로 확인되었다. 배출가스 온도가 해당 범위에 존재할 때, 물질수지 측면에 서 적절한 공기공급량과 배출가스 온도에 의해 수분 제거량 이 최대가 되었고, 열수지 측면에서는 유기물 분해에 의한 대사열 발생량과 공기공급에 의한 대류열 및 반응기 외벽에 서의 전도열 손실량 간의 적절한 균형에 의해 수분 제거를 위한 증발잠열로의 손실량이 최대가 되었기 때문으로 해석 될 수 있다.

2) 상온의 공기를 공급하기보다 가온된 공기 $\left(50^{\circ} \mathrm{C}\right.$ 이상 $)$ 를 공급함과 동시에 공기공급량을 증가시켜 배출가스 온도 제어범위를 낮춤으로써 건조 성능 및 효율이 향상되었으며, 이는 건조 열원으로 유기물 분해에 의한 대사열 뿐만 아니 라 고온의 공기공급에 의한 대류열도 함께 활용되기 때문인 것으로 확인되었다. 그러나 이는 과량의 공기가 공급되는 만큼 배출가스 처리용량이 최소 1.5 배 이상 증가되어야 함 을 의미한다.

3) Bio-drying 공정에 대한 성능 및 효율 평가 지표로 수 분 제거속도, 수분 제거능 및 수분 제거비를 적용할 수 있으 며, 특히 수분 제거비는 건조에 대한 열적 효율을 대체할 수 있음이 확인되었다. 다만, 이러한 지표를 활용함에 있어 bio-drying 공정에 특정된 범위 또는 최소 요구치 등의 산정 에 대한 방안이 마련되어야 할 것으로 사료된다.

\section{Acknowledgement}

본 연구는 환경부의 “폐자원에너지화 기술개발사업”의 지원 을 받았으며, 이에 감사드립니다(과제번호: 2018001570001). 


\section{References}

1. Ministry of Environment, Statistics of Sewerage in 2018, Ministry of Environment, Sejong, South Korea(2019).

2. D. Đurđević, M. Trstenjak, I. Hulenić, Sewage sludge thermal treatment technology selection by utilizing the analytical hierarchy process, Water, 12(5), 1255(2020).

3. C. A. Velis, P. J. Longhurst, G. H. Drew, R. Smith, S. J. T. Pollard, Biodrying for mechanical - biological treatment of wastes: a review of process science and engineering, Bioresour. Technol., 100(11), 2747-2761(2009).

4. C. Huiliñir, M. Villegas, Simultaneous effect of initial moisture content and airflow rate on biodrying of sewage sludge, Water Res., 82, 118-128(2015).

5. J. Ma, L. Zhang, A. Li, Energy-efficient co-biodrying of dewatered sludge and food waste: synergistic enhancement and variables investigation, Waste Manage., 56, 411-422 (2016).

6. B. Yang, L. Zhang, D. Jahng, Importance of initial moisture content and bulking agent for biodrying sewage sludge, Drying Technol., 32(2), 135-144(2014).

7. L. Zhao, W. M. Gu, P. J. He, L. M. Shao, Effect of air-flow rate and turning frequency on bio-drying of dewatered sludge, Water Res., 44(20), 6144-6152(2010).

8. L. Zhao, W. Gu, L. Shao, P. He, Sludge bio-drying process at low ambient temperature: effect of bulking agent particle size and controlled temperature, Drying Technol., 30(10), 1037-1044(2012).

9. S. Navaee-Ardeh, F. Bertrand, P. R. Stuart, Development and experimental evaluation of a $1 \mathrm{D}$ distributed model of transport phenomena in a continuous biodrying process for pulp and paper mixed sludge, Drying Technol., 29(2), 135-152(2011).

10. C. Huiliñir, J. Pérez, D. Olivares, A new model of batch biodrying of sewage sludge, part 1: model development and simulations, Drying Technol., 35(6), 651-665(2017).

11. J. Zhang, T. B. Chen, D. Gao, Simulation of the mathematical model of composting process of sewage sludge, Compost Sci. Util., 24(2), 73-85(2016).

12. H. B. Zhou, T. B. Chen, D. Gao, G. D. Zheng, J. Chen, T. H. Pan, H. T. Liu, R. Y. Gu, Simulation of water removal process and optimization of aeration strategy in sewage sludge composting, Bioresour. Technol., 171, 452-460(2014).

13. J. I. Chang, J. J. Tsai, K. H. Wu, Mathematical model for carbon dioxide evolution from the thermophilic composting of synthetic food wastes made of dog food, Waste Manage., 25(10), 1037-1045(2005).

14. R. Smith, R. G. Eilers, Numerical simulation of activated sludge composting, EPA-600/2-80-191, USEPA, Cincinnati, OH, USA(1980).

15. L. Rosso, J. R. Lobry, J. P. Flandrois, An unexpected correlation between cardinal temperatures of microbial growth highlighted by a new model, J. Theor. Biol., 162(4), 447-463(1993).

16. A. De Guardia, C. Petiot, J. C. Benoist, C. Druilhe, Characterization and modelling of the heat transfers in a pilot-scale reactor during composting under forced aeration, Waste Manage., 32(6), 1091-1105(2012).

17. I. G. Mason, Predicting biodegradable volatile solids degradation profiles in the composting process, Waste Manage., 29(2), 559-569(2009).

18. F. Adani, D. Baido, E. Calcaterra, P. Genevini, The influence of biomass temperature on biostabilization biodrying of municipal solid waste, Bioresour. Technol., 83(3), 173-179(2002).

19. C. Liang, K. C. Das, R. W. McClendon, The influence of temperature and moisture contents regimes on the aerobic microbial activity of a biosolids composting blend, Bioresour. Technol., 86(2), 131-137(2003).

20. J. Ma, L. Zhang, L. Mu, K. Zhu, A. Li, Thermally assisted bio-drying of food waste: synergistic enhancement and energetic evaluation, Waste Manage., 80, 327-338(2018).

\section{Authors}

\section{Jae-Ram Park}

Department of Environmental Engineering, University of Seoul, Ph.D. Candidate, ORCID (D) 0000-0003-4176-2004

\section{Dong-Hoon Lee}

Department of Environmental Engineering, University of Seoul, Professor, ORCID (D) 0000-0002-9482-5083

\section{Kyung-Hyun Kim}

Jinenertech Inc., Research Director, ORCID (이 0000-0003-14307436 